OPEN ACCESS

Edited by:

Krishna Mohan Poluri, Indian Institute of Technology

Roorkee, India

Reviewed by:

Oana Ciofu,

University of Copenhagen, Denmark

Mariana Carmen Chifiriuc,

University of Bucharest, Romania

*Correspondence:

Shigeki Nakamura

shigenak@tokyo-med.ac.jp

Specialty section:

This article was submitted to

Antimicrobials, Resistance

and Chemotherapy,

a section of the journal

Frontiers in Microbiology

Received: 18 March 2021

Accepted: 31 May 2021

Published: 05 July 2021

Citation:

Yang X, Haque A, Matsuzaki S,

Matsumoto T and Nakamura S (2021)

The Efficacy of Phage Therapy in a

Murine Model of Pseudomonas

aeruginosa Pneumonia and Sepsis.

Front. Microbiol. 12:682255.

doi: 10.3389/fmicb.2021.682255

\section{The Efficacy of Phage Therapy in a Murine Model of Pseudomonas aeruginosa Pneumonia and Sepsis}

\author{
Xu Yang ${ }^{1}$, Anwarul Haque ${ }^{1,2}$, Shigenobu Matsuzaki ${ }^{3}$, Tetsuya Matsumoto ${ }^{1,2}$ and \\ Shigeki Nakamura ${ }^{1 *}$
}

'Department of Microbiology, Tokyo Medical University, Tokyo, Japan, ${ }^{2}$ Department of Infectious Diseases, School of Medicine, International University of Health and Welfare, Narita, Japan, ${ }^{3}$ Department of Medical Laboratory Science, Kochi Gakuen University, Kochi, Japan

The emergence of multi-drug resistant Pseudomonas aeruginosa necessitates the search for treatment options other than antibiotic use. The use of bacteriophages is currently being considered as an alternative to antibiotics for the treatment of bacterial infections. A number of bacteriophages were introduced to treat pneumonia in past reports. However, there are still lack of knowledge regarding the dosages, application time, mechanism and safety of phage therapy against $P$. aeruginosa pneumonia. We used the bacteriophage KPP10 against $P$. aeruginosa strain D4-induced pneumonia mouse models and observed their outcomes in comparison to control models. We found that the nasal inhalation of highly concentrated KPP10 $(\mathrm{MOI}=80)$ significantly improved survival rate in pneumonia models $(P<0.01)$. The number of viable bacteria in both lungs and in serum were significantly decreased $(P<0.01)$ in phage-treated mice in comparison to the control mice. Pathological examination showed that phagetreated group had significantly reduced bleeding, inflammatory cell infiltration, and mucus secretion in lung interstitium. We also measured inflammatory cytokine levels in the serum and lung homogenates of mice. In phage-treated models, serum TNF $\alpha$, $\mathrm{IL}-1 \beta$, and IFN- $\gamma$ levels were significantly lower $(P<0.05, P<0.01$, and $P<0.05$, respectively) than those in the control models. In the lung homogenate, the mean IL$1 \beta$ level in phage-treated models was significantly lower $(P<0.05)$ than that of the control group. We confirmed the presence of phage in blood and lungs, and evaluated the safety of bacteriophage use in living models since bacteriophage mediated bacterial lysis arise concern of endotoxic shock. The study results suggest that phage therapy can potentially be used in treating lung infections caused by Pseudomonas aeruginosa.

Keywords: Pseudomonas aeruginosa, pneumonia, sepsis, bacteriophage, phage therapy

\section{INTRODUCTION}

Pseudomonas aeruginosa is a gram-negative opportunistic pathogen and is one of the main pathogens that cause nosocomial infections. It is a common etiology for infections in immunocompromised patients (Parker et al., 2008; Gellatly and Hancock, 2013) and in respiratoryassociated pneumonia in ICU settings. Antimicrobial therapy is the choice of treatment 
in Pseudomonas infections; however, due to the emergence of multi-drug resistant $P$. aeruginosa, there have been cases wherein antibiotics have failed (Nathwani et al., 2014; Jernigan et al., 2020). Phage therapy is considered as a treatment option against bacterial infections because of its ability to lyse bacterial cells. Compared to antimicrobial therapy, phage therapy has advantages such as high specificity, sterilization, selfpropagation, and protection of mutation-mediated antibioticresistance development (Matsuzaki et al., 2005). In recent years, due to the emergence of multi-drug resistant bacteria, phage therapy has attracted widespread attention due to its possession of a completely different mechanism of action compared to antibiotic therapy (Viertel et al., 2014).

Although phage therapy has a long history, the safety of phage therapy has not yet been fully studied (Caflisch et al., 2019; Kwiatek et al., 2020) especially in the context of infections caused by gram-negative bacteria that pose a risk of endotoxemia (Buttenschoen et al., 2010; Dickson and Lehmann, 2019). Endotoxins are present in the cell walls of most gram-negative bacteria, and even very low doses can strongly trigger human inflammatory reactions, and in severe cases can cause endotoxin shock and death (Lepper et al., 2002; Surbatovic et al., 2013). Like bactericidal antibiotics, bacteriophage causes release of endotoxins when they lyse gram-negative bacteria (Dufour et al., 2017). Past reports showed that phage therapy was used in children to treat persistent lung infections with cystic fibrosis caused by $P$. aeruginosa (Krylov et al., 2016; Parkins et al., 2018); however, there are several reports of pneumonia with $P$. aeruginosa in patients with non-cystic fibrosis (Patey et al., 2019). Therefore, we aimed to evaluate the therapeutic effect of phage therapy on pulmonary $P$. aeruginosa infection using animal models.

\section{MATERIALS AND METHODS}

\section{Bacteria Strain}

The $P$. aeruginosa standard strain D4 was isolated from the blood of neutropenic mice which had bacteremia (Matsumoto et al., 1997a,b, 1998a,b,c; Watanabe et al., 2007); this was stored in LB medium containing $50 \%$ glycerol at $-80^{\circ} \mathrm{C}$.

\section{Animal Care and Use}

Six weeks old Male, pathogen-free, ICR mice that were purchased (Sankyo Labo Service Co., Ltd.) and were housed under specificpathogen-free conditions and were supplemented with standard laboratory food and water ad libitum. The facility was maintained at a constant temperature $\left(27^{\circ} \mathrm{C}\right)$, humidity $(65 \%)$, and $12 / 12 \mathrm{~h}$ light/dark cycle.

\section{Anesthesia Protocol}

The anesthesia mixture used was prepared by combining the following: $2 \mathrm{~mL}$ midazolam (5 mg/mL; FUJIFILM Wako Co., Ltd.), Vetorphale $2.5 \mathrm{~mL}$ (5 mg/mL; Meiji Seika Pharma Co., Ltd.), medetomidine hydrochloride $0.75 \mathrm{~mL}$ (1 mg/ml; Kyoritsu Seiyaku), normal saline $19.75 \mathrm{~mL}$ (Otsuka Pharmaceutical Co.,
Ltd.). The mice were anesthetized by subcutaneously injecting the anesthesia mixer at a dose of $0.1 \mathrm{~mL} / 10 \mathrm{~g}$. The animal study was reviewed and approved by Tokyo Medical University Animal Care and Use Committee.

\section{Phage}

Using $P$. aeruginosa strain (P20) as the host, bacteriophage strain KPP10 was isolated from a water sample collected from a river in Kochi Prefecture, Japan. Strain P20 was derived from clinical specimens of Kochi Medical University Hospital in Kochi Prefecture, Japan. The KPP10 bacteriophage belongs to the Myoviridae family, morphological type A1, and has strong lytic activity against $P$. aeruginosa D4 (Watanabe et al., 2007; Uchiyama et al., 2012). Previous reports indicate that bacteriophage KPP10 is a lytic bacteriophage, which has no pathogenicity or pathogenicity-related genes, so it is expected to be very suitable for use as a therapeutic bacteriophage (Uchiyama et al., 2012).

\section{Bacteriophage Culture}

LB medium was inoculated with $1 \% \mathrm{v} / \mathrm{v}$ of overnight bacterial culture at the exponential growth phase and was incubated at $37^{\circ} \mathrm{C}$ for $2 \mathrm{~h}$ to reach an approximate $\mathrm{OD}_{600}$ of $0.2-0.4$. Then, the phage was added at MOI $=10$ and was incubated at $37^{\circ} \mathrm{C}$ for $5 \mathrm{~h}$ with gentle stirring $(100 \mathrm{rpm})$ to facilitate cell lysis. Cell debris was removed by centrifugation $(20 \mathrm{~min}, 1,750 \times g$, $4^{\circ} \mathrm{C}$ ). The supernatant was filtered using a $0.22 \mu \mathrm{m}$ disposable filter (CORNING 430521) and the phage were stored at $4^{\circ} \mathrm{C}$ for downstream use.

\section{Phage Count}

The phages were counted using the plaque assay method according to standard protocols (Parker et al., 2008). Phage dilutions were prepared using physiological saline. Using 2\% agar as the bottom layer, $20 \mathrm{~mL}$ of LB agar medium (Sigma) containing $100 \mu \mathrm{L}$ of phage dilution and $100 \mu \mathrm{L}$ of exponentially growing bacterial solution were plated on agar plates at $45^{\circ} \mathrm{C}$. The plate was then incubated at $37^{\circ} \mathrm{C}$ overnight, afterward, the plaques were counted.

\section{PEG Precipitation}

The bacteriophage was mixed with polyethylene glycol (PEG) 6000 [10\% total (wt/vol); FUJIFILM Wako] and $\mathrm{NaCl}(0.5 \mathrm{M}$; FUJIFILM Wako), and were kept in rotation overnight at $4^{\circ} \mathrm{C}$. Then, these were centrifuged for $15 \mathrm{~min}$ at a speed of $11,000 \times g$ in $4^{\circ} \mathrm{C}$ (TOMY RX200) to collect the precipitate, and pellet was suspended in phage buffer to dilute the phage concentration 200 times. We noticed that the use of ultracentrifugation to concentrate the phage solution led to ammonium acetate and cesium chloride release, which proved to be toxic. As such, we used high-speed centrifugation in the presence of PEG precipitation. In the method described by Bourdin et al. (2014) chloroform was used to remove bacterial proteins in the concentrate after centrifugation; however, KPP10 is not chloroform-resistant (data not shown), so this step was omitted. 


\section{Pseudomonas aeruginosa Pneumonia Model}

Pseudomonas aeruginosa $\mathrm{D} 4$ cultured on $\mathrm{LB}$ agar plates overnight at $37^{\circ} \mathrm{C}$ was adjusted to $2.5 \times 10^{9}$ colony forming unit $(\mathrm{CFU}) / \mathrm{mL}$ using sterile physiological saline. To produce the $P$. aeruginosa pneumonia model, $20 \mu \mathrm{l}$ of bacterial suspension was inoculated through intranasal route in anesthetized mice. These mice were randomly divided in two groups and $10 \mu \mathrm{L}$ of KPP10 bacteriophage $\left(4 \times 10^{11} / \mathrm{mL}\right.$ plaque forming unit, $\mathrm{PFU})(\mathrm{MOI}=80)$ was administered in these mice intranasally after $2 \mathrm{~h}$ (group 1) and $8 \mathrm{~h}$ (group 2) of bacterial inoculation. Past study suggested that higher dose (MOI) of bacteriophage can promptly kill bacteria and help to minimize the chance of resistant development to phage (Taha et al., 2018). In addition, another study using in-vitro models showed that KPP10 became resistant to $P$. aeruginosa $\mathrm{D} 4$ strains at $210 \mathrm{~min}$. of administration (Watanabe et al., 2007). Considering number and short therapeutic window of phage from these studies, we administered the bacteriophage in mice at a highest concentration (MOI) that we could harvest in our laboratory $(\mathrm{MOI}=80)$. The mice in negative control $(\mathrm{NC})$ group were inhaled $10 \mu \mathrm{L}$ of phage buffer after $2 \mathrm{~h}$ of inoculation. We used imipenem/cilastatin sodium to prepare a positive control (PC) group. After $2 \mathrm{~h}$ post inoculation of $P$. aeruginosa, $25 \mathrm{mg} / \mathrm{kg}$ of imipenem/cilastatin sodium (MSD Co., Ltd.) was injected subcutaneously to a group of randomly selected mice at every $12 \mathrm{~h}$ for 3 days (Coopersmith et al., 2003). All groups were monitored daily for 6 days to calculate their survival rate.

Analysis of survival data showed that there was no significant difference in survival rates between the mice those inhaled KPP10 at $2 \mathrm{~h}$ and $8 \mathrm{~h}$ p.i. Therefore, in the bacteriology and histopathology experiments we only included the Pa pneumonia mice inhaled either phage KPP10 or phage buffer at $2 \mathrm{~h}$ p.i.

\section{Pathological Examination of Lung Tissue}

After $2 \mathrm{~h}$ of inhalation of $20 \mu \mathrm{L} P$. aeruginosa $\mathrm{D} 4\left(1.25 \times 10^{9} / \mathrm{mL}\right.$ $\mathrm{CFU})$, the treatment group inhaled $10 \mu \mathrm{L}$ phage KPP10 $\left(2 \times 10^{11} / \mathrm{mL} \mathrm{PFU}\right)$, and the control group inhaled $10 \mu \mathrm{L}$ of sterile phage buffer. After $24 \mathrm{~h}$, mice were euthanized by isoflurane inhalation. The lungs and trachea were removed under sterile conditions, and the specimens were fixed with $10 \%$ formalin (FUJIFILM Wako). The specimen was embedded and sliced, and then stained with H\&E stain.

\section{Determination of Viable Bacteria and Phage in the Lung and Serum}

Pseudomonas aeruginosa pneumonia mice were randomly divided in treatment and control groups. After $2 \mathrm{~h}$ post infection, the treatment group inhaled $10 \mu \mathrm{L}(\mathrm{MOI}=80)$ of phage KPP10 $\left(2 \times 10^{11} \mathrm{PFU} / \mathrm{mL}\right)$, and the control group inhaled $10 \mu \mathrm{L}$ of phage buffer. After $24 \mathrm{~h}$, live mice were euthanized by isoflurane inhalation to collect their blood from cardiac ventricles and the whole lung under sterile conditions. A tissue homogenizer (Nakayama Co., Ltd., 16-80) was used to homogenize the lung tissues in physiological saline, after which EDTA (final concentration $0.05 \mathrm{M}$ ) was added, and the tissue debris were removed by centrifugation at $8,000 \times g$ for $2 \mathrm{~min}$ at $4^{\circ} \mathrm{C}$. Collected lungs were kept on ice during all steps. Blood samples were coagulated in a vacuum blood collection tube (Nipro Corporation Limited), and the serum was separated from blood cells by centrifugation at $10,000 \times g$ for $5 \mathrm{~min}$. The serum and lung tissue homogenate samples were diluted with sterile physiological saline and inoculated on NAC agar plates (Eiken Chemical Co., Ltd.), and incubated at $37^{\circ} \mathrm{C}$ for $24 \mathrm{~h}$.

Serum and lung tissue homogenate samples were prepared using physiological saline. Using $2 \%$ agar as the bottom layer, $20 \mathrm{~mL}$ of LB agar medium (Sigma) containing $100 \mu \mathrm{L}$ of samples and $100 \mu \mathrm{L}$ of exponentially growing bacterial solution were plated on agar plates at $45^{\circ} \mathrm{C}$. The plate was then incubated at $37^{\circ} \mathrm{C}$ overnight, afterward the plaques were counted. Serum and lung tissue homogenate samples were stored at $-30^{\circ} \mathrm{C}$ for downstream analyses.

\section{Measurement of Cytokine and High Mobility Group Box 1 (HMGB1) Level}

TNF- $\alpha$, IL- $1 \beta$, and IFN- $\gamma$ concentrations in serum and lung tissue samples and serum HMGB1 concentration were assayed using mouse uncoated ELISA Kit (Thermo Fisher Scientific, MA, United States) and mouse/rat HMGB1 ELISA Kit (Arigo Biolaboratories Co., Ltd., Hsinchu City, Taiwan) according to the manufacturer's protocols, respectively.

\section{Determination of Endotoxin Levels in Serum}

We used a commercial limulus amebocyte lysate (LAL) endotoxin detection kit (FUJIFILM Wako) to measure the endotoxin levels of the collected mouse serum samples. Mouse serum samples were diluted 10-fold using physiological saline (Otsuka Pharmaceutical). Then, $100 \mu \mathrm{L}$ of the diluted serum sample was added to the endotoxin sample pretreatment solution (FUJIFILM Wako), mixed, and incubated at $70^{\circ} \mathrm{C}$ for $10 \mathrm{~min}$, after which ice water was immediately added to the mixture and to cool for $2 \mathrm{~min}$. Afterward, $200 \mu \mathrm{L}$ of the treated sample was then added to the LAL reagent, thoroughly mixed, and measurement was done using Toxinometer MT-6500 (FUJIFILM Wako).

\section{Statistical Analysis}

Survival analysis was performed using the chi-square test, and the survival rate by the Kaplan-Meier method. All other assay data are presented as the mean \pm standard deviation (SD). Differences between groups were examined using the Mann-Whitney $U$ test $(P$ values $<0.05$ were considered to indicate a statistically significant difference).

\section{RESULTS}

\section{Survival Rate of Pseudomonas aeruginosa Pneumonia Model}

In order to evaluate whether KPP10 has a protective effect against pneumonia caused by $P$. aeruginosa $\mathrm{D} 4$, we compared survival 


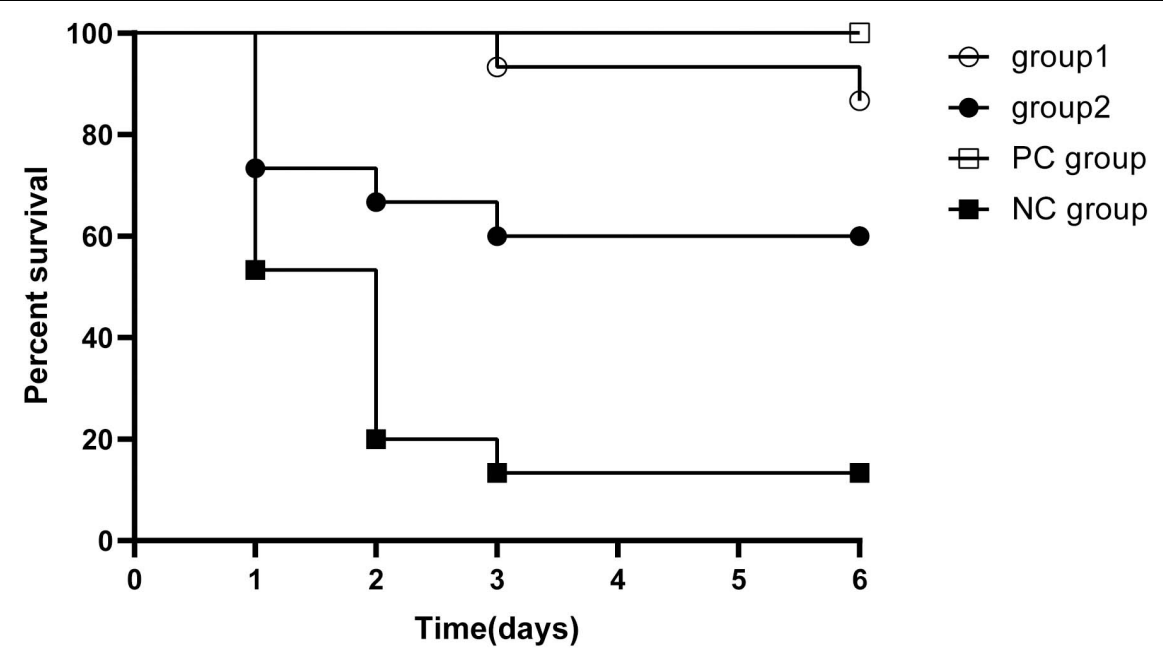

FIGURE 1 | Survival rate in pneumonia mice. All mice inhaled $20 \mu \mathrm{L}$ P. aeruginosa D4 (2.5 × $\left.10^{9} \mathrm{CFU} / \mathrm{ml}\right)$. Group 1 ( $\left.n=15\right)$ inhaled $10 \mu \mathrm{l}$ phage KPP10 (10 $\mu$ l $\left.4 \times 10^{11} \mathrm{PFU} / \mathrm{ml}\right)$ at $2 \mathrm{~h}$ post bacterial inoculation. Group $2(n=15)$ inhaled $10 \mu \mathrm{l}$ phage KPP10 $\left(10 \mu \mathrm{l} 4 \times 10^{11} \mathrm{PFU} / \mathrm{ml}\right)$ at $8 \mathrm{~h}$ post bacterial inoculation. Negative control (NC) group inhaled $10 \mu \mathrm{L}$ of phage buffer at $2 \mathrm{~h}$ post bacterial inoculation and the positive control (PC) group received subcutaneous injection imipenem/cilastatin sodium ( $25 \mathrm{mg} / \mathrm{kg}$ ) at $2 \mathrm{~h}$ post infection and at every $12 \mathrm{~h}$ interval for 3 days. Survival rate in group 1 , group 2 and PC mice were significantly higher $(p<0.01$ ) when individually compared with the survival rate of NC mice. CFU denotes colony forming unit. PFU denotes plaque forming unit.

rates between four groups (Figure 1). The survival rate of mice in the group 1, group 2 and the PC group were significantly higher when individually compared with that of the NC mice $(87 \%$ vs. $13 \%$; $p<0.01,60 \%$ vs. $13 \%$; $p<0.01,100 \%$ vs. $13 \%$; $p<0.01)$. The survival rate between group 1 and group 2 and between group 1 mice and PC group had no significant differences $(87 \%$ vs. $60 \% ; p=0.99,87$ vs. $100 \% ; p=0.143)$. This indicates that KPP10 has a protective effect against pneumonia caused by $P$. aeruginosa D4. Moreover, even with an administration of phage at a delayed time point of post infections, survival rate in pneumonic mice improved.

\section{Pathological Examination}

In order to confirm the effect of KPP10 on pneumonia caused by $P$. aeruginosa $\mathrm{D} 4$, we observed pathological changes in the lung tissues of phage-treated and control mice; results are shown in Figure 2. We observed that $24 \mathrm{~h}$ after $P$. aeruginosa inhalation, a large number of bacteria were present in the lungs of the control mice (Figure 2B). The alveoli were filled with red blood cells and mucus, and there was a tendency for severe pulmonary bleeding. Inflammatory cell infiltration in the lung interstitium was also observed. In contrast, in the lungs of treated mice, $P$. aeruginosa D4 was observed to be cleared, the observed bleeding tendency was mild, and only a small amount of RBCs were left in the pulmonary interstitium (Figure 2D). This indicates that KPP10 effectively eliminated $P$. aeruginosa D4 in the lungs.

\section{Number of Viable Bacteria and Phage in Lung and Serum}

To confirm the effect of KPP10 on P. aeruginosa D4 in the lungs, we counted the viable bacteria and phage in the mouse lungs and serum. As shown in Figure 3, the number of viable bacteria in the lungs of the phage treatment group was significantly lower than that of the control group (treatment group 3,165 CFU/lung vs. control group 227,250 CFU/lung; $p<0.01$ ) (Figure 3A), and the number of viable bacteria in the serum of the phage treatment group was also significantly lower than that of the control group (treatment group $64 \mathrm{CFU} / \mathrm{mL}$ vs. control group $202,111 \mathrm{CFU} / \mathrm{mL} ; p<0.01$ ) (Figure 3B). This indicates that the $P$. aeruginosa D4 was significantly cleared from lungs and blood of the mice at $24 \mathrm{~h}$ post inhalation of KPP10. On the contrary, a large number of viable phages were persisting in the lungs in phage treatment group (2,217,833,333 PFU/lung), and the viable phages were also detected in serum (170 PFU/mL) (Figure 3C).

A question could be raised that bacteriophage came in contact with bacteria during harvesting and platting procedures and it could be worth if bacteria is separated from phage or phage activity is blocked by any means before culturing the bacteria in lungs and serum. A number of past studies (Watanabe et al., 2007; Mai et al., 2015; Hua et al., 2018) showed phage efficacy, in particularly phage KPP10 efficacy, in infection models describing the correlation between survival and bacterial numbers in circulation and in different organs in infected and control models. In our study, we followed the same method to demonstrate the efficacy of KPP10 in Pa infection models. In addition, we kept the collected samples on ice during all steps from the harvesting to culturing, which should reduce the activities of bacteria and phage to a minimum level without affecting their viability.

\section{Cytokine Levels in Serum and Lung Tissue Homogenate Samples}

We measured the levels of inflammatory cytokines TNF $\alpha$, IL-1 $\beta$, IFN- $\gamma$, and HMGB1 in the mice serum and lung homogenates. In the serum samples, levels of TNF $\alpha$, IL- $1 \beta$ and IFN- $\gamma$ in the phage-treated mice were significantly lower than those in the control mice (TNF $\alpha$ in treatment group: $185.82 \mathrm{pg} / \mathrm{mL}$ vs. 


\section{A}

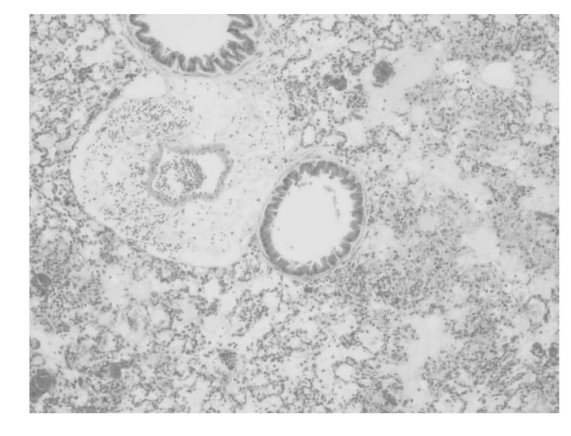

C

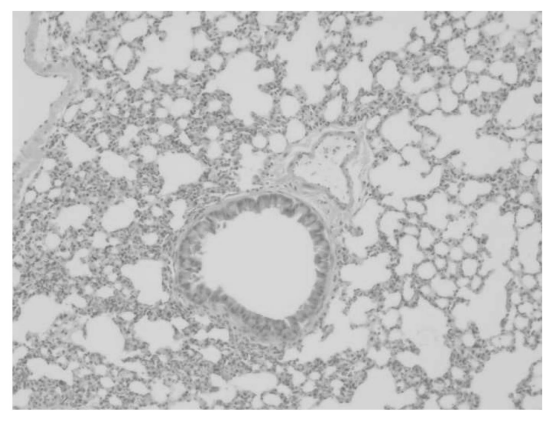

B

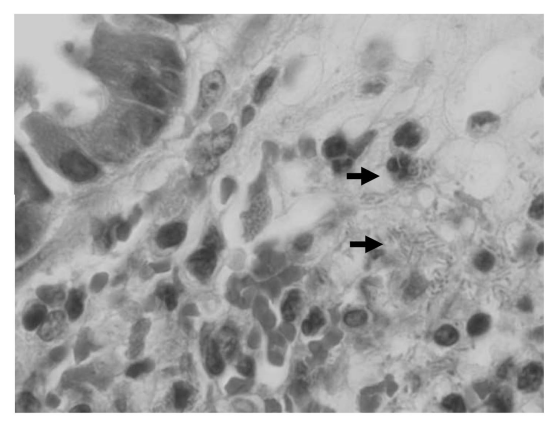

D

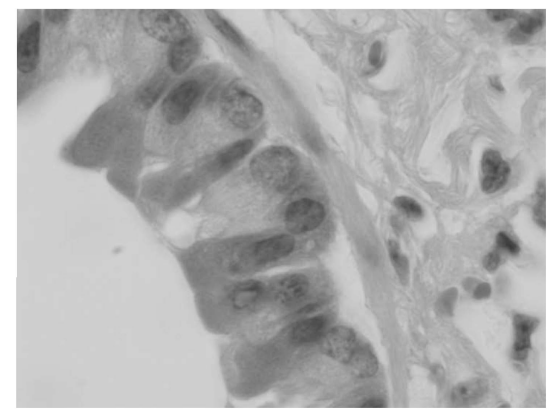

FIGURE 2 | Pathological micrograph of mouse lungs. In the control group $(n=6), 50 \times$ magnification (A) showed that the alveoli were filled with red blood cells and mucus, and a tendency of severe pulmonary bleeding was observed. At 1,000 $\times$ magnification (B), there are a large number of bacteria in the lungs, and inflammatory cell infiltrations in the lung interstitium can be seen. In the treatment group $(n=6)$, a small amount of red blood cells in the alveoli can be seen at $50 \times$ magnification (C). At 1,000 × magnification (D), the infiltration of inflammatory cells can be seen whereas no bacteria can be found.

control group: 3,026.24 pg/mL; $p<0.05$; IL-1 $\beta$ in treatment group: $130.60 \mathrm{pg} / \mathrm{mL}$ vs. control group: $3,910.77 \mathrm{pg} / \mathrm{m} ; p<0.01$; IFN- $\gamma$ in treatment group: $307.02 \mathrm{pg} / \mathrm{mL}$ vs. control group: 2,192.05 pg/mL; $p<0.05$ ) (Figure 4B). There was no significant difference observed in HMGB1. In the lung samples after tissue homogenization, the IL-1 $\beta$ level of the phage-treated group was significantly lower than that of the control group (treatment group: 2,179.33 pg/lung vs. control group 6,099.86 pg/lung; $p<0.05)$, TNF $\alpha$ level showed a decreasing tendency, whereas IFN- $\gamma$ and HMGB1 showed an increasing tendency (Figure 4A).

\section{Endotoxin Levels of Serum Samples}

To assess whether $P$. aeruginosa D4-induced pneumonia treated with KPP10 may introduce a risk of endotoxic shock, we measured the endotoxin levels in the serum of mice. As shown in Figure 5, endotoxin levels in the serum of the phage treatment group were significantly lower than those of the control group (treatment group: $38.51 \mathrm{pg} / \mathrm{mL}$ vs. control group: $2,337.03 \mathrm{pg} / \mathrm{mL} ; p<0.01)$. The decreased endotoxin (LPS) level in phage treated mice reflects the lower number of bacteria in mice circulation, which also correlate with the data of bacterial burden in phage-treated and non-treated mice in this study.

\section{DISCUSSION}

Pseudomonas aeruginosa is an important opportunistic pathogen, and its strong adaptability enables it to survive in various environments including surfaces of medical devices (Gellatly and
Hancock, 2013). This makes $P$. aeruginosa one of the common pathogens causing pneumonia in patients relying on mechanical ventilation (Parker et al., 2008). P. aeruginosa has strong natural resistance to antibiotics, and its acquired antibiotic resistance is also gradually increasing (Berube et al., 2016). In terms of the need for new antibiotics due to increase in antibiotic resistance, the World Health Organization has classified $P$. aeruginosa under Priority 1 (Critical), which means that the establishment of phage therapy as a treatment modality that can replace antibiotic therapy is urgent [Viertel et al., 2014; World Health Organization (WHO), 2013]. Here, we showed that phage therapy is comparable with antimicrobial therapy for treating $P$. aeruginosa pneumonia.

Decrement of bacterial load in infected host due to bactericidal effect of phage is a known phenomenon (Rodriguez-Gonzalez et al., 2020). In this study, quantification of live bacteria and phage in the lungs and serum and, pathological changes in lung fields in experimental models are corresponding to the phenomenon. Moreover, we observed that the pneumonic mice those didn't receive phage therapy mostly died within 24 h post infection. This finding supports the notion that phage replication rate in suitable bacteria is very high and it causes lysis of the infected bacteria within several hours (Payne and Jansen, 2001). Our study evident that the early administration of phage (at $2 \mathrm{~h}$ post infection) saved more infected mice than that of later administration at $8 \mathrm{~h}$ post infection. It is noticeable that the phage level in the lungs of the phage-treated mice was very high at $24 \mathrm{~h}$ p.i. It can be explained by the well-known characteristics of phage, that it releases progeny bacteriophages during lysis of 
A

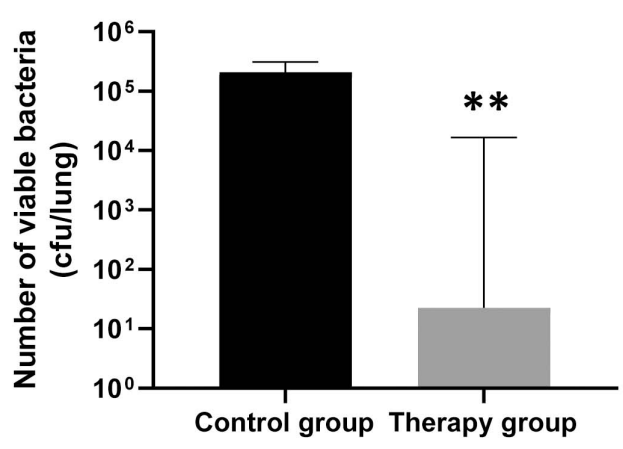

C
B

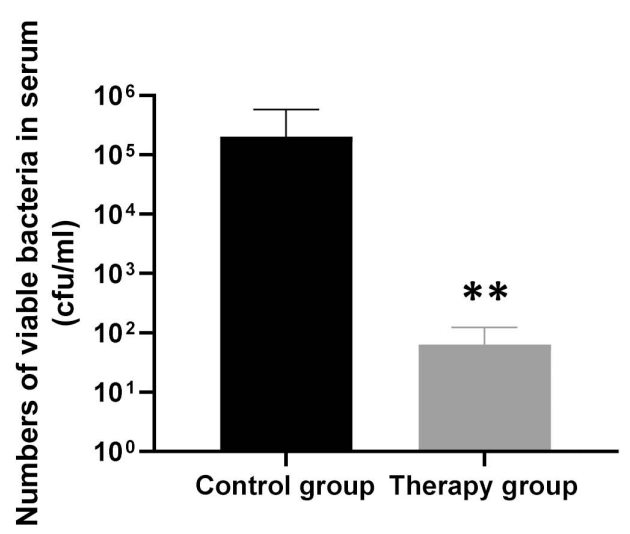

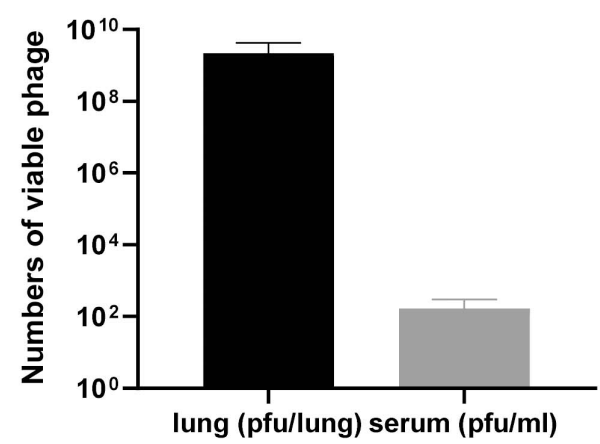

FIGURE 3 | The number of viable bacteria and phage in the lungs and serum of mice $24 \mathrm{~h}$ after infection. The number of viable bacteria in the lungs (A), the phage treatment group $(n=6)$ was significantly lower than that of the control group $(n=6)$. The number of viable bacteria in the serum (B), the phage treatment group $(n=6)$ was also significantly lower than that of the control group $(n=6)$. Data are presented as mean \pm SEM of two experiments. The number of viable phages in the lungs and serum (C) of phage-treated mice $24 \mathrm{~h}$ after infection. Data are presented as mean \pm SEM of two experiments ( ${ }^{\star *}<0.01$ vs. untreated control). CFU denotes colony forming unit. PFU denotes plaque forming unit.

bacteria. We have to admit that nasal inhalation of bacteria and bacteriophages cannot guarantee their even distribution in the lungs and multiple bacteriophages may infect the same bacteria due to the very high MOI. The number of bacteriophages in the area with low MOI will increase while the number of phages in the area with a higher MOI will decrease. This is the cause why phage level in the lungs of the mice in the treatment group remained high or basically unchanged at $24 \mathrm{~h}$ p.i.

Although previous many studies made pneumonia models in their experimental animals using inhalation of bacteria, but didn't consider or describe the development of pulmonary septicemia in their models (Debarbieux et al., 2010; Forti et al., 2018). Here in our study, we explored the presence of bacteria and bacteriophage in blood, indicating that phage inhalation is not only beneficial to protect pulmonary infections but also to manage the septicemia triggered by pulmonary infections.

There is evidence that when a local acute bacterial infection occurs, $\mathrm{T}$ cells become activated and infiltrate the infected site (Sadikot et al., 2005). Infiltrating $\mathrm{T}$ cells produce IFN$\gamma$ to enhance phagocytic cells, especially polymorphonuclear neutrophils (PMN), to combat bacterial infection (Wagner et al., 2008). This may explain why phage-treated mice had high levels of IFN- $\gamma$ in the lungs and very low levels of IFN- $\gamma$ in the serum. We believe that this is beneficial in combating $P$. aeruginosamediated lung infections.
HMGB1 is considered to be the lethal endogenous mediator of endotoxins in mice. HMGB1 can be produced under the stimulation of endotoxins, TNF $\alpha$, and IL-1 $\beta$ (Martinotti et al., 2015); moreover, recent studies have shown that cell damage also leads to HMGB1 expression (Kang et al., 2014). The levels of endotoxin, TNF $\alpha$, and IL- $1 \beta$ in the phage treatment group were significantly lower than those in the control group, but the level of HMGB1 were higher than that of the control group. This suggests that treatment with KPP10 may induce cell damage. Here, we did not include experiments that would exclude the effects of cell damage, which is a limitation of our study.

Since 1900, phage therapy has been widely studied as treatment against bacterial infections. Phage therapy has many advantages: it has bactericidal properties, is self-generating, has little effect on normal microflora, is also effective against antibiotic-resistant bacteria, and seems to be able to destroy bacterial biofilms (Harper et al., 2014); however, controversy still exists regarding safety of phage therapy. While phages do not infect human cells, the endotoxin released by the phage associated Gram negative bacteria during bactericidal process of phage may trigger endotoxic shock in patients (Dickson and Lehmann, 2019). Phage therapy is currently used to treat skin infections and persistent lung infections in patients with cystic fibrosis (Krylov et al., 2016; Chang et al., 2020). The safety of phage therapy for treatment of acute lung infections caused 
A

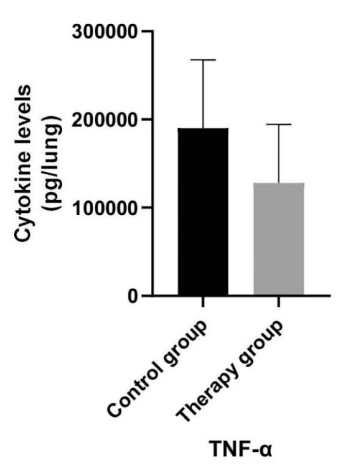

B

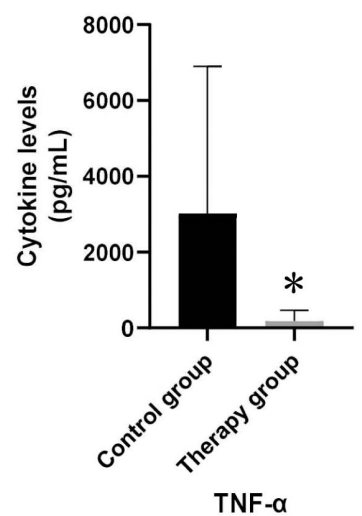

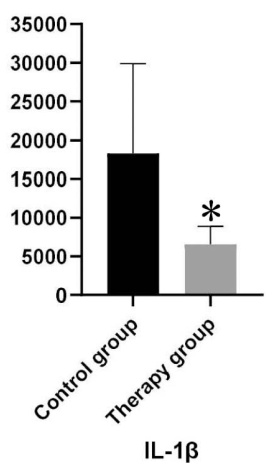

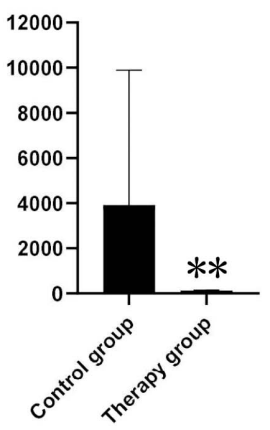

IL-1 $\beta$
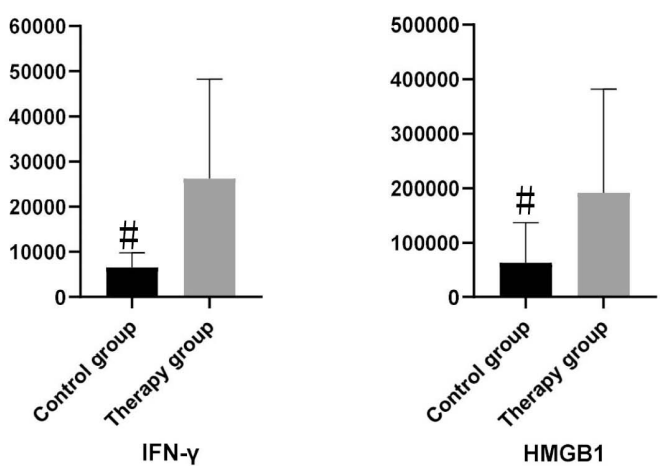

HMGB1
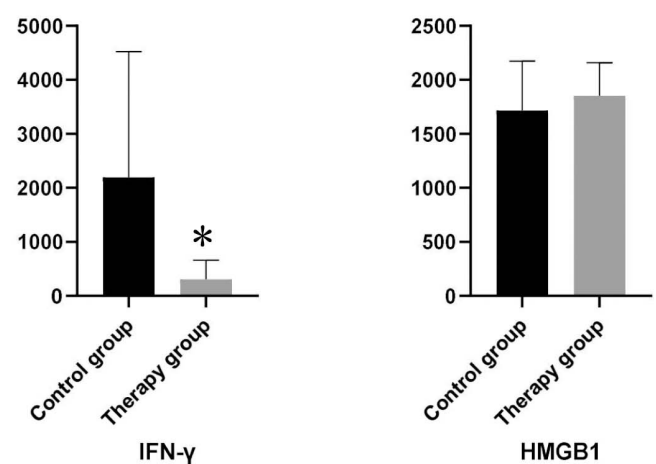

FIGURE 4 | The levels of inflammatory cytokines in mouse lungs and serum. In lung samples (A), the levels of IL-1 $\beta$ in phage-treated mice $(n=6)$ were significantly lower than those in control mice $(n=6)$. In serum samples $(\mathbf{B})$, the levels of TNF- $\alpha, \mathrm{IL}-1 \beta$ and IFN- $\gamma$ in phage-treated group were significantly lower than that of the control group, however, HMGB1 had no significant difference. Data are presented as mean \pm SEM of two experiments (* $<0.05$, ${ }^{\star *}<0.01$ vs. untreated control).

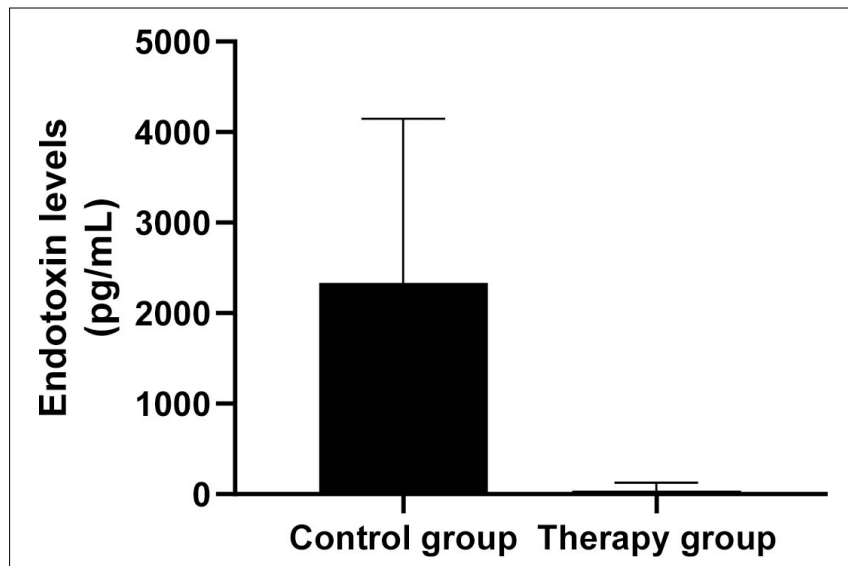

FIGURE 5 | Endotoxin levels in mouse serum. The level of endotoxin in the serum of phage-treated mice $(n=6)$ was significantly lower than that of the control mice $(n=6)$. Data are presented as mean \pm SEM of two experiments $\left({ }^{\star *}<0.01\right.$ vs. untreated control). et al., 2007). We find that inhaled KPP10 also exerts a significant protective effect against pneumonia caused by $P$. aeruginosa D4.

The additional advantages of KPP10 bacteriophage and $P$. aeruginosa D4 strain are that the detail genomic data of these elements are readily available. No study investigated KPP10 against $P$. aeruginosa pneumonia before ours, although many phages have been studied in the past. We noticed that in some studies those used the same animal models as ours, the survival rate of the phage treatment group did not reach $100 \%$, which can often be achieved by antibiotic therapy (Hua et al., 2018; Jeon and Yong, 2019). However, bacteriological data showed that the level of bacteria in the lung was significantly reduced. Therefore, we are concerned that phage therapy has the risk of causing endotoxic shock. Considering effectiveness and safety of phage KPP10 revealed by this study, phage therapy may be useful in treating lung $P$. aeruginosa infections. Further research should be conducted to elucidate the safety of phage therapy and the possibility of it being used as an alternative treatment in clinical settings.

\section{DATA AVAILABILITY STATEMENT}

The raw data supporting the conclusions of this article will be made available by the authors, without undue reservation. 


\section{ETHICS STATEMENT}

The animal study was reviewed and approved by Tokyo Medical University Animal Care and Use Committee.

\section{AUTHOR CONTRIBUTIONS}

SN and TM: conception and design of the study, interpretation of data, and review the article. $\mathrm{XY}$ and $\mathrm{AH}$ : analysis and

\section{REFERENCES}

Berube, B. J., Rangel, S. M., and Hauser, A. R. (2016). Pseudomonas aeruginosa: breaking down barriers. Curr. Genet. 62, 109-113. doi: 10.1007/s00294-0150522-x

Bourdin, G., Schmitt, B., Guy, L. M., Germond, J. E., Zuber, S., Michot, L., et al. (2014). Amplification and purification of T4-Like Escherichia coli phages for phage therapy: From laboratory to pilot scale. Appl. Environ. Microbiol. 80, 1469-1476. doi: 10.1128/AEM.03357-13

Buttenschoen, K., Radermacher, P., and Bracht, H. (2010). Endotoxin elimination in sepsis: Physiology and therapeutic application. Langenbeck's Arch. Surg. 395, 597-605. doi: 10.1007/s00423-010-0658-6

Caflisch, K. M., Suh, G. A., and Patel, R. (2019). Biological challenges of phage therapy and proposed solutions: a literature review. Expert Rev. Anti. Infect. Ther. 17, 1011-1041. doi: 10.1080/14787210.2019.1694905

Chang, R. Y. K., Morales, S., Okamoto, Y., and Chan, H. K. (2020). Topical application of bacteriophages for treatment of wound infections. Transl. Res. 220, 153-166. doi: 10.1016/j.trsl.2020.03.010

Coopersmith, C. M., Amiot, D. M., Stromberg, P. E., Dunne, W. M., Davis, C. G., Osborne, D. F., et al. (2003). Antibiotics improve survival and alter the inflammatory profile in a murine model of sepsis from Pseudomonas aeruginosa pneumonia. Shock 19, 408-14. doi: 10.1097/01.shk.0000054370.24363.ee

Debarbieux, L., Leduc, D., Maura, D., Morello, E., Criscuolo, A., Grossi, O., et al. (2010). Bacteriophages can treat and prevent pseudomonas aeruginosa lung infections. J. Infect. Dis. 201, 1096-104. doi: 10.1086/651135

Dickson, K., and Lehmann, C. (2019). Inflammatory response to different toxins in experimental sepsis models. Int. J. Mol. Sci. 20:341. doi: 10.3390/ijms20184341

Dufour, N., Delattre, R., Ricard, J. D., and Debarbieux, L. (2017). The lysis of pathogenic Escherichia coli by bacteriophages releases less endotoxin than by B-lactams. Clin. Infect. Dis. 64, 1582-1588. doi: 10.1093/cid/cix184

Forti, F., Roach, D. R., Cafora, M., Pasini, M. E., Horner, D. S., Fiscarelli, E. V., et al. (2018). Design of a broad-range bacteriophage cocktail that reduces pseudomonas aeruginosa biofilms and treats acute infections in two animal models. Antimicrob. Agents Chemother. 62, 2573-17. doi: 10.1128/AAC. 02573-17

Gellatly, S. L., and Hancock, R. E. W. (2013). Pseudomonas aeruginosa: New insights into pathogenesis and host defenses. Pathog. Dis. 67, 159-173. doi: 10.1111/2049-632X.12033

Harper, D. R., Parracho, H. M. R. T., Walker, J., Sharp, R., Hughes, G., Werthén, M., et al. (2014). Bacteriophages and biofilms. Antibiotics 3, 270-284. doi: 10.3390/antibiotics3030270

Hua, Y., Luo, T., Yang, Y., Dong, D., Wang, R., Wang, Y., et al. (2018). Phage therapy as a promising new treatment for lung infection caused by carbapenemresistant Acinetobacter baumannii in mice. Front. Microbiol. 2017:659. doi: 10.3389/fmicb.2017.02659

Jeon, J., and Yong, D. (2019). Two novel bacteriophages improve survival in Galleria mellonella infection and mouse acute pneumonia models infected with extensively drug-resistant Pseudomonas aeruginosa. Appl. Environ. Microbiol. 128, 2900-18. doi: 10.1128/AEM.02900-18

Jernigan, J. A., Hatfield, K. M., Wolford, H., Nelson, R. E., Olubajo, B., Reddy, S. C., et al. (2020). Multidrug-resistant bacterial infections in U.S. hospitalized patients, 2012-2017. N. Engl. J. Med. 382, 1309-1319. doi: 10.1056/ NEJMoa1914433

Kang, R., Chen, R., Zhang, Q., Hou, W., Wu, S., Cao, L., et al. (2014). HMGB1 in health and disease. Mol. Aspects Med. 40, 1-116. interpretation of data, collection and assembly of data, and drafting of the article. SM: phage preparation. All authors contributed to the article and approved the submitted version.

\section{ACKNOWLEDGMENTS}

We would like to thank T. Sugawara (Tokyo Medical University Hospital Central Clinical Laboratory) for his technical assistance.

Krylov, V., Shaburova, O., Pleteneva, E., Bourkaltseva, M., Krylov, S., Kaplan, A., et al. (2016). Modular approach to select bacteriophages targeting Pseudomonas aeruginosa for their application to children suffering with cystic fibrosis. Front. Microbiol. 7:631. doi: 10.3389/fmicb.2016.01631

Kwiatek, M., Parasion, S., and Nakonieczna, A. (2020). Therapeutic bacteriophages as a rescue treatment for drug-resistant infections - an in vivo studies overview. J. Appl. Microbiol. 128, 985-1002. doi: 10.1111/jam.14535

Lepper, P., Held, T., Schneider, E., Bölke, E., Gerlach, H., and Trautmann, M. (2002). Clinical implications of antibiotic-induced endotoxin release in septic shock. Intensive Care Med. 28, 824-833. doi: 10.1007/s00134-002-1330-6

Mai, V., Ukhanova, M., Reinhard, M. K., Li, M., and Sulakvelidze, A. (2015). Bacteriophage administration significantly reduces shigella colonization and shedding by shigella-challenged mice without deleterious side effects and distortions in the gut microbiota. Bacteriophage 2015:124. doi: 10.1080/ 21597081.2015.1088124

Martinotti, S., Patrone, M., and Ranzato, E. (2015). Emerging roles for HMGB1 protein in immunity, inflammation, and cancer. Immuno Targets Ther. 4, 101-109.

Matsumoto, T., Tateda, K., Furuya, N., Miyazaki, S., Ohno, A., Ishii, Y., et al. (1998a). Efficacies of alkaline protease, elastase and exotoxin A toxoid vaccines against gut-derived Pseudomonas aeruginosa sepsis in mice. J. Med. Microbiol. 47, 303-308. doi: 10.1099/00222615-47-4-303

Matsumoto, T., Tateda, K., Miyazaki, S., Furuya, N., Ohno, A., Ishii, Y., et al. (1998b). Effect of immunisation with Pseudomonas aeruginosa on gut-derived sepsis in mice. J. Med. Microbiol. 47, 295-301. doi: 10.1099/00222615-47-4-295

Matsumoto, T., Tateda, K., Miyazaki, S., Furuya, N., Ohno, A., Ishii, Y., et al. (1998c). Effect of interleukin-10 on gut-derived sepsis caused by Pseudomonas aeruginosa in mice. Antimicrob. Agents Chemother. 42, 2853-2857. doi: 10.1128/ aac.42.11.2853

Matsumoto, T., Tateda, K., Miyazaki, S., Furuya, N., Ohno, A., Ishii, Y., et al. (1997a). Immunomodulating effect of fosfomycin on gut-derived sepsis caused by Pseudomonas aeruginosa in mice. Antimicrob. Agents Chemother. 41, 308313. doi: 10.1128/aac.41.2.308

Matsumoto, T., Tateda, K., Miyazaki, S., Furuya, N., Ohno, A., Ishii, Y., et al. (1997b). Adverse effects of tumour necrosis factor in cyclophosphamide-treated mice subjected to gut-derived Pseudomonas aeruginosa sepsis. Cytokine 9, 763-769. doi: 10.1006/cyto.1997.0222

Matsuzaki, S., Rashel, M., Uchiyama, J., Sakurai, S., Ujihara, T., Kuroda, M., et al. (2005). Bacteriophage therapy: A revitalized therapy against bacterial infectious diseases. J. Infect. Chemother. 11, 211-219. doi: 10.1007/s10156-005-0408-9

Nathwani, D., Raman, G., Sulham, K., Gavaghan, M., and Menon, V. (2014). Clinical and economic consequences of hospital-acquired resistant and multidrug-resistant Pseudomonas aeruginosa infections: A systematic review and meta-analysis. Antimicrob. Resist. Infect. 3:32. doi: 10.1186/2047-2994-3-32

Parker, C. M., Kutsogiannis, J., Muscedere, J., Cook, D., Dodek, P., Day, A. G., et al. (2008). Ventilator-associated pneumonia caused by multidrug-resistant organisms or Pseudomonas aeruginosa: Prevalence, incidence, risk factors, and outcomes. J. Crit. Care 23, 18-26. doi: 10.1016/j.jcrc.2008.02.001

Parkins, M. D., Somayaji, R., and Waters, V. J. (2018). Epidemiology, Biology, and Impact of Clonal Pseudomonas aeruginosa Infections in Cystic Fibrosis. Clin. Microbiol. Rev. 31:19. doi: 10.1128/CMR.00019-18

Patey, O., McCallin, S., Mazure, H., Liddle, M., Smithyman, A., and Dublanchet, A. (2019). Clinical indications and compassionate use of phage therapy: Personal experience and literature review with a focus on osteoarticular infections. Viruses 11:18. doi: 10.3390/v11010018 
Payne, R. J. H., and Jansen, V. A. A. (2001). Understanding bacteriophage therapy as a density-dependent kinetic process. J. Theor. Biol. 208, 37-48. doi: 10.1006/ jtbi. 2000.2198

Rodriguez-Gonzalez, R. A., Leung, C. Y., Chan, B. K., Turner, P. E., and Weitz, J. S. (2020). Quantitative models of phage-antibiotic combination therapy. mSystems 5:784. doi: 10.1101/633784

Sadikot, R. T., Blackwell, T. S., Christman, J. W., and Prince, A. S. (2005). Pathogenhost interactions in pseudomonas aeruginosa pneumonia. Am. J. Respir. Crit. Care Med. 171, 1209-1223. doi: 10.1164/rccm.200408-1044SO

Surbatovic, M., Jevdjic, J., Veljovic, M., Popovic, N., Djordjevic, D., and Radakovic, S. (2013). Immune response in severe infection: Could life-saving drugs be potentially harmful? Sci. World J. 2013:852. doi: 10.1155/2013/ 961852

Taha, O. A., Connerton, P. L., Connerton, I. F., and El-Shibiny, A. (2018). Bacteriophage ZCKP1: A potential treatment for Klebsiella pneumoniae isolated from diabetic foot patients. Front. Microbiol. 2018:127. doi: 10.3389/fmicb.2018. 02127

Uchiyama, J., Rashel, M., Takemura, I., Kato, S., Ujihara, T., Muraoka, A., et al. (2012). Genetic characterization of Pseudomonas aeruginosa bacteriophage KPP10. Arch. Virol. 157, 733-738. doi: 10.1007/s00705-011-1210-x

Viertel, T. M., Ritter, K., and Horz, H. P. (2014). Viruses versus bacteria-novel approaches to phage therapy as a tool against multidrug-resistant pathogens. J. Antimicrob. Chemother. 69, 2326-2336. doi: 10.1093/jac/dku173
Wagner, C., Kotsougiani, D., Pioch, M., Prior, B., Wentzensen, A., and Hänsch, G. M. (2008). T lymphocytes in acute bacterial infection: Increased prevalence of CD11b+ cells in the peripheral blood and recruitment to the infected site. Immunology 125, 503-509. doi: 10.1111/j.1365-2567.2008.02863.x

Watanabe, R., Matsumoto, T., Sano, G., Ishii, Y., Tateda, K., Sumiyama, Y., et al. (2007). Efficacy of bacteriophage therapy against gut-derived sepsis caused by Pseudomonas aeruginosa in mice. Antimicrob. Agents Chemother. 51, 446-452. doi: 10.1128/AAC.00635-06

World Health Organization (2013). Global Priority List of Antibiotic-Resistant Bacteria to Guide Research, Discovery, and Development of New Antibiotics. Geneva: WHO.

Conflict of Interest: The authors declare that the research was conducted in the absence of any commercial or financial relationships that could be construed as a potential conflict of interest.

Copyright (c) 2021 Yang, Haque, Matsuzaki, Matsumoto and Nakamura. This is an open-access article distributed under the terms of the Creative Commons Attribution License (CC BY). The use, distribution or reproduction in other forums is permitted, provided the original author(s) and the copyright owner(s) are credited and that the original publication in this journal is cited, in accordance with accepted academic practice. No use, distribution or reproduction is permitted which does not comply with these terms. 